\title{
GREECE'S “CHANGING” ISRAELI AND “UNCHANGING” EGYPTIAN POLICY
}

\author{
Assoc. Prof. İsmail ŞAHIN (Ph.D.) * \\ Asst. Prof. Hanefi YAZICI (Ph.D.) * iD
}

\begin{abstract}
The purpose of this article is to examine Greece's policies related to Egypt and Israel in the context of regional developments. The issue is not limited to those two countries only. In addition, Athens' historical perspective on Turkey is also included in the analysis in order to ensure the integrity of the issue. The factors determining the foreign policy of the Greek governments towards Israel are included and the elements of continuity and rupture in that policy are examined throughout the article. A similar method is used related to the Greece-Egypt relations. The reason why Greece's Israeli policy changed and its Egyptian policy did not change is questioned comparatively through the threat perceptions of Athens. The reasons bringing Israel and Greece closer to each other are dealt with in this context. Accordingly, it has been determined that the two countries first entered a normalization period and then a rapprochement process due to pragmatist reasons in the face of regional developments.
\end{abstract}

Keywords: Greece, Israel, Egypt, East Mediterranean, Foreign Policy.

\section{INTRODUCTION: GEOPOLITICAL IMPORTANCE OF GREECE}

Greece occupies an important geopolitical position amongst Southeast Europe, Asia and Africa. Surrounded by the Ionian Sea on the west, the Islands (Aegean) Sea on the east, and the Mediterranean Sea on the south, Greece has a strong dominance over seas and lands. Therefore, it has always attracted the attention of global actors in the power struggle. It is known that Greece, which has a strategic advantage in the Balkans, which are at the front door of Europe, is the subject of frequently updated political calculations among the states waging a struggle for influence in this geography. It is seen that England during the 19th century and the United States of America (USA) afterwards established close relations with Greece in order to prevent Russia from establishing influence in the Balkans. It is observed that Greece, which was the place of an important power struggle between the USA and the Soviet Union during the Cold War Period, is now the scene of geopolitical conflicts with its military bases and energy transmission lines.

\footnotetext{
* Ankara Hacı Bayram Veli University, Faculty of Economics and Adminstrative Sciences, Department of International Relations, Ankara/ Turkey. E-mail: ismailshn@gmail.com

* Bandırma Onyedi Eylül University, aculty of Economics and Adminstrative Sciences, Department of International Relations, Balıkesir/ Türkiye. E-mail: hyazici@bandirma.edu.tr
}

Makale Gecmisi/Article History 
Another important global value for Greece is its role in shipping. It is seen that the Greeks, who have the quality of being a maritime nation, utilize that characteristic in maritime trade. One of the biggest goals of Greece, which has an important global shipping capacity in world maritime trade, is to become a global leader in maritime trade. Currently, one-fifth of the global maritime transport, and about fifty percent of European maritime transport, is under the control of Greece. This situation is remarkable in that it indicates the high level of competitive power of Greece in maritime transport. There is another aspect of it that affects diplomacy because the role of foreign economic relations is very important in the diplomatic capacity of a country. As a matter of fact, the commercial and economic relations developed by states along with the political relations established in their international relations have an undeniable scope. It is possible to show many examples regarding the issue in the history of international relations.

Ultimately, measuring the weight of a country in foreign policy only with its political and military capacity will not be an adequate approach to make a comprehensive analysis. Therefore, the economic and commercial ties that a country establishes with the outside world contribute to that country's international recognition, image, in short, its soft power on the one hand and they allow it to find more support and allies, especially in an international issue on the other hand. In short, the economic and commercial relations of a country are an important power. First of all, those relations allow it to conduct diplomacy in a wider geography. In this context, the public-private sector cooperation within the country is of particular importance. Considering that diplomacy has long lost its qualification as a special field carried out only by official institutions in global conditions where the free-market economy is the rule, the value of the private sector and its connections with the outside world have become apparent. The coordination and cooperation that Greece has established between the public and private sectors on foreign policy issues come to fruition in diplomatic fields. In particular, the physical conveniences offered by many islands that Greece owns strengthen the role and position of the country in maritime transportation, and its ability to be an effective trade and maritime crossroads. In this context, the country's global business networks it has developed through fields such as maritime trade, maritime industry, shipyards and maritime tourism give Greek diplomacy great advantages (Harlaftis, 1996: 298). For example, Greece's privileged position in the Mediterranean and in the maritime sector facilitated China's close interest in this country and the conclusion of comprehensive cooperation agreements between the two countries (Le Corre, 2018: 12-21).

\section{FOREIGN POLICY PRIORITIES OF GREECE}

As it is often stated, foreign policy is a process of decision making (Pevehouse and Goldstein, 2015: 185). In this context, there are many components and factors that affect the process of decision making. Greece is a state that has experienced phases that can radically affect the political and social order of a state, such as independence, occupation, civil war, cold war, military coup and junta 
administration. In addition, it is a country that has experienced the discussions of kingdomparliamentary republic, an issue of national dichotomy. Besides, Greece adopted the ideology Megali Idea (Great Idea) as a foreign policy paradigm from the first half of the 19th century to the first half of the 20th century and made intense diplomatic efforts for the construction of "Greater Greece" in this direction. All of the issues mentioned above are the main events and phenomena that have nurtured Greek philosophy of foreign policy. As a result of those events and phenomena, it is seen that a geopolitical foreign policy idea that is based on Hellenism and a national historical narrative, heavily nurtured by religious-cultural nationalism, (Heraclides, 2002: 39), and caring about the regional power balance dominates Greece. When it is viewed a little more closely, it can be said that the analysis of threats and risks to national security has shaped Greek foreign policy. In this context, the Slavs from the north and the Turks from the east have been described as the historical enemies of the Greek nation that wanted the elimination of Hellenism; and that point of view has been passed on to generations through schools.

Since the Cyprus Peace Operation carried out by Turkey in 1974, the main enemy of Greece has been Turkey (Heraclides, 2002: 38). According to the Greek politics and public opinion, Turkey's intervention in Cyprus is a concrete outcome of Ankara's "aggressive and expansionist" policy. That idea is evident in Greek foreign policy decisions and acts; a tougher and more aggressive foreign policy has been carried out against Turkey since 1974. Declaring war against Turkey was not a realistic attitude because when the two countries were compared in terms of military capacity, the balance was against Greece. According to Athens, the inequality between the armed forces could only be balanced by diplomacy. Nevertheless, in order to quell the public anger and to give a concrete response to Turkey, Greece started to mass troops and weapons on the Greek islands close to the Turkish coast (Clogg, 1997: 214). This act caused the deepening and growth of the continental shelf crisis that broke out in the Aegean Sea between the two countries in 1973. Although Turkey claimed that Greece violated both the Treaty of Lausanne (1923) and the Treaty of Paris (1947) by placing troops and weapons on the islands close to the Western Anatolian coast, the Greek governments argued that those attempts were a "defense" against Turkish "expansionism and aggression". In the following years, the problem of territorial waters between the two countries regarding the Aegean Sea came to light.

In 1982, the United Nations Convention on the Law of the Sea allowed littoral countries to extend their territorial sea border up to 12 miles, which led to a demand by Greece to expand its territorial sea border to 12 miles in the Aegean Sea. Considering the Treaty of Lausanne, the parties used to accept the 3 nautical miles stipulated for the territorial sea border in the Aegean Sea. However, using the Montreux Convention as an excuse, Greece unilaterally increased its territorial sea border to 6 miles in 1936. It is understood that Turkey did not object to this unilateral arrangement due to the political conjuncture at that time. It is a generally accepted assumption that Ankara did not react in any way due to the joy 
created by the Montreux Convention and the positive atmosphere that dominated Turkish-Greek relations at that time. Turkey reacted so strongly to the demand of Athens to expand its territorial waters to 12 miles that the Grand National Assembly of Turkey stated in a decision taken at its session on 8 June 1995 that it would consider Greece's extension of its territorial waters to 12 miles in the Aegean Sea as a reason for war (casus belli) (Şahin ve Günar, 2021: 48). There are important problems between Greece and Turkey regarding Cyprus, the Aegean Sea and minorities. According to Athens, the only conflict that can be negotiated between the two countries is the continental shelf issue; Turkey is completely wrong related to other issues. Ankara, on the other hand, demands a comprehensive discussion of the three issues mentioned above and their subheadings. Just like Athens, Ankara holds the other party responsible as the cause of the disputes. Mutual accusations and showdowns in some cases caused the relations between the two NATO allies to deteriorate further.

Greece is among the most nationalistic countries of the European Union (EU). It followed an irredentist policy during the stages of independence, establishment and growth. What is probably more important is that the irredentist policy based on the Megali Idea is regarded as legitimate and just by Athens. Although Greece is a liberal state that is a member of the EU and NATO and that is governed by a parliamentary republic, ${ }^{1}$ it pursues a very nationalistic line in foreign policy issues. One of the reasons for that is the weight of the nationalist school in the Greek Ministry of Foreign Affairs. According to that school, Turkey is a revisionist force against peace and order in the region (Heraclides, 2002: 43). However, an armed struggle against Turkey is not seen as a rational choice in Athens. Besides, the problems between the two countries are not at a level to necessitate a war. Moreover, organizations such as the UN, EU and NATO and other major international actors are in favor of the settlement of the problems between the two neighboring countries through peaceful methods. Even though there are serious conflicts between Ankara and Athens in the Aegean Sea, that place is not in the category of conflict zones. Despite the chronic and complex nature of the problems, diplomacy is still the only way out for both countries.

It is a known fact that Turkey's increasing geopolitical power in recent years has disturbed and worried Greece as much as the insolubility of the problems between the two countries. It is also believed that Turkey's becoming a stronger country in military, political and economic aspects will increase the pressure on Greece. Some commentators even claim that if Athens does not take the necessary measures, it may become a satellite of Turkey. In the articles published in the press and academic journals, it is possible to see the argument that Turkey showed through the Cyprus operation (1974) that it could change the borders in Thrace and the Aegean Sea. It was not surprising that the commentators holding that view also interpreted Turkey's "Euphrates Shield" (2016) and "Olive Branch" (2018) operations targeting Syrian territory from the same perspective. Therefore, the assumption that Ankara intends to

\footnotetext{
${ }^{1}$ Monarchy regime ended in Greece in 1974 and the country started to be ruled by republican regime. 
Yönetim ve Ekonomi Arașttrmaları Dergisi / Journal of Management and Economics Research

Cilt/Volume: $19 \quad$ Sayl/Issue: 3 Eylül/September 2021 ss./pp. 115-138

İ. Şahin, H. Yazıcı http://dx.doi.org/10.11611/yead.974239

change the borders drawn by the Treaty of Lausanne and the Treaty of Paris with revisionist policies was one of the issues at the top of the agenda of Athens. Many pieces of news or comments that Ankara "challenged the Treaty of Lausanne" by constantly bringing up the issue of borders occupied the Greek press.

The most important issue for Greece is to maintain the balance of power with Turkey. Acting upon that strategy, Athens resorts to the policy of surrounding Turkey. Accordingly, forming an antiTurkish axis or bloc in the Caucasus, the Middle East and the Balkans, where Turkey could be influential, is regarded as a rational choice. In addition, Greece aims to benefit from Turkey-EU, TurkeyUSA and Turkey-Russia conflicts in the maximum way. Besides, strengthening the Greek defense and deterrence and in this context, strengthening the military power capacity in the islands, Thrace and Cyprus are regarded as an effective move. The political choices of Athens reminiscent of the power strategies of the Cold War Period caused it to pursue a foreign policy in the region that constantly put Turkey in its center, and in this direction, it sought anti-Turkish coalitions or alliances to isolate Turkey. Naturally, this situation has brought about a great obstacle to the development of Turkish-Greek relations through dialogue, diplomacy or a win-win formula.

When the Balkans, Black Sea and Middle East policy of Greece is examined, it is seen that the need to limit Turkey's regional power is among the foreign policy priorities of Greece. According to Athens, Turkey's expansionist and revisionist tendencies can be prevented only if it is surrounded in a determined and watchful manner. The driving force of such a foreign policy choice, as it is mentioned above, is the strong suspicion that Turkey is trying to gain influence in the countries established within the borders of the former empire by using economic, religious and cultural tools. Acting upon that suspicion, Greek foreign policy designers accept the strategy of containment as an appropriate option in terms of keeping Turkey mentally and physically within the limits determined by the Treaty of Lausanne. Therefore, it has been adopted as an obligatory choice to strengthen bilateral relations with Arab states, Balkan countries, Armenia and Russia, and particularly to strengthen cooperation networks with anti-Turkish governments in the region. In addition, claiming that the countries of the region are directly or indirectly exposed to Turkey's aggression and in this direction, trying to be the spokesperson for the countries of the region in the European Union, the United Nations and the USA have been followed as a complementary strategy. It is understood that another diplomatic act that has been agreed upon is to expand the EU's responsibility area towards North Africa and the Middle East through the areas of close cooperation established with North African and Middle Eastern countries together with South Cyprus Greek Administration (SCGA). It can be said that the approach of Greek politicians and diplomats to the Arab Spring and specifically to the political events in Egypt is within the framework of that understanding. Moreover, Athens was very worried about the development of events within the framework of the domino theory so much so that, in case of a regime change in Egypt that will bring the 
Yönetim ve Ekonomi Arașttrmaları Dergisi / Journal of Management and Economics Research

Cilt/Volume: $19 \quad$ Sayl/Issue: 3 Eylül/September 2021 ss./pp. 115-138

İ. Şahin, H. Yazıcı http://dx.doi.org/10.11611/yead.974239

Muslim Brotherhood to power, it was assumed that it would influence the countries neighboring Egypt one by one, and each would turn into a satellite of Turkey. Greek foreign policy designers, who interpreted the possible changes in the North African countries as contrary to their national and regional interests, evaluated Turkey's support for the Arab Spring as a new threat both politically and militarily. In an environment where Turkey's military, economic and political power were growing, its close relations with North Africa were perceived as a historical threat to Greece's national security, and the political rivalry between the two states tried to be presented as the struggle between 'good' and 'evil' by Greece in order to gain the support of the international public in the disputes between Turkey and Greece.

\section{BURGAS-ALEXANDROUPOLIS OIL PIPELINE PROJECT}

The Burgas-Alexandroupolis oil pipeline project, signed in March 2007 in Athens by Russian President Vladimir Putin, Bulgarian Prime Minister Sergey Stanishev and Greek Prime Minister Kostas Karamanlis, led to concerns that it would increase Europe's dependence on Russia for energy and was reacted by the USA and the European Union. As a matter of fact, according to the USA and the EU, Russia uses oil and natural gas as an important diplomatic tool to regain the power it had before the collapse of the Soviet Union. Besides, the project was not considered very reasonable in terms of both its cost-benefit and possible effects on the environment.

The project divided the oil transportation into three phases. In the first step, oil would be brought from the Russian Novorosisk Port to the Bulgarian Burgas Port by tankers. In the second phase, oil would be transported from Burgas Port to Alexandroupolis via a pipeline of approximately 288 kilometers to be built. In the last stage, the oil would be reloaded from Alexandroupolis Port to tankers and transported to international markets. 51 percent of the pipeline project would belong to Russia, and the remainder would be equally owned by Greece and Bulgaria. There were two important reasons why Greece attached importance to the project: one economic and the other political. It was estimated that the project would bring an annual transfer fee of 30 to 50 million dollars to Greece. In fact, that figure was not very significant for Athens. The main economic goal of Greece was to transport most of the oil to be shipped from Alexandroupolis Port to world markets by Greek tankers. Politically, Athens' expectation was far beyond the economic expectation. The pipeline would connect the Black Sea and the Aegean Sea, bypassing the straits. In addition, it would be a serious rival to the Baku-Tbilisi-Ceyhan oil pipeline. The fact that Turkey became an important corridor country in transporting the Caucasus, Caspian and Central Asian oil and gas to the world markets caused discomfort in Athens due to geopolitical concerns. In this context, the Burgas-Alexandroupolis oil pipeline project had the potential to become an important rival to the Baku-Tbilisi-Ceyhan oil pipeline inaugurated in 2006. On the other hand, it was clear that this new project would conflict with Turkey's interests and would disturb it. 
Besides, Turkey opposed to the Burgas-Alexandroupolis oil pipeline project from the very beginning for various reasons. Caspian and Middle Eastern oil resources began to be transported to international markets via the Baku-Tbilisi-Ceyhan oil pipeline and hence made a significant contribution to the increase of Turkey's geopolitical importance. Therefore, the Burgas-Alexandroupolis oil pipeline project was perceived as a serious rival. Criticism of the project was not limited to Turkey. In fact, the project was neither profitable nor efficient in terms of transportation costs. There was a remarkable reaction to the project, which was signed during the years when the Socialist Party was in power in Bulgaria, that it would not provide any economic and political benefits to Bulgaria. For example, in the local referendum held for Bulgarian citizens living in Burgas and Sozopol in 2008, people voted against the pipeline project. Many people interpreted the project in terms of the Socialist Party's proximity to Moscow. The full membership of Bulgaria to the EU in 2007 and the center-right "Citizens for the European Development of Bulgaria" (GERB) party led by Boyko Borisov coming to power in 2009 increased the reactions against the Burgas-Alexandroupolis oil pipeline project, eventually bringing about a series of developments that led to the cancellation of the project. In addition to financial and ecological concerns, the worry that Bulgaria's dependence on Russia for energy would increase triggered the decision of the Bulgarian government to withdraw from the Burgas-Alexandroupolis pipeline project in December 2011. This decision taken by the government was accepted in the Bulgarian Parliament in March 2013 and became definite. After Bulgaria withdrew from the project, the BurgasAlexandroupolis pipeline project, one of the largest energy projects for Athens, could not be realized.

\section{INCREASED CONCERNS IN THE EASTERN MEDITERRANEAN}

It is understood that after the failure of the Burgas-Alexandroupolis pipeline project, Greece focused on the Eastern Mediterranean energy resources. Greece has been one of the leading states that have claimed the most rights on the Mediterranean since its independence. Therefore, from the past to the present, the Mediterranean has been a region in which Athens is closely interested politically, culturally, militarily and economically. Since the beginning of the 2000 s, serious social and political transformations have occurred in the littoral countries of the Eastern Mediterranean or in the countries of the region interacting with the littoral countries. A series of events called the "Arab Spring", which started at the end of 2010, soon affected the North African countries and spread from there to Syria, inevitably led to public security concerns such as terrorism, migration and refugee crisis in the countries of the region. In this context, Athens followed closely the events from Tunisia to Syria with concern.

The most important reason for it was the migration movement that started towards safe countries when the search for freedom and the struggle for democracy in Arab countries were drawn into bloody events leading to civil wars. The biggest fear of Greece, which is one of the important transit countries of the European migration route, was to be exposed to a large flow of migration. Greece was facing the most important economic crisis in its history at that time and the number of unemployment reached 
record levels due to the economic bankruptcy. The economic crisis, which overturned the economic order, led to the rise of racist attitudes, xenophobia and anti-immigration attitudes throughout the country. Rising racism and opposition to immigration caused immigrants and refugees who wanted to reach the European Union to be exposed to "shameful" practices in Greece (BBC, Accessed 20.12.2020). Those practices are also mentioned in the reports published by Amnesty International.

It is seen that Greece, which was shaken by political, economic and social crises, placed its political attitude towards Eastern Mediterranean energy resources on two main axes. The first one is to support the strategic relations that South Cyprus Greek Administration (SCGA) established with Israel and Egypt. The second is to ensure that the EU will support this issue. According to Athens, Turkey is the biggest rival and threat in the Black Sea, Aegean and Eastern Mediterranean. ${ }^{2}$ The possibility of Turkey's rising to a key position in meeting Europe's energy needs and the concern that this status could move Turkey to a more valuable position in the eyes of the EU and NATO, led Athens to a bilateral disturbance. In fact, Athens wants Greece to play a central role in the transportation of the Black Sea, the Caspian Sea and the Mediterranean energy resources. Therefore, it is possible to say that Athens has adopted a policy against Turkey's gaining an indispensable position in the energy supply of Europe. In line with the foreign policy approach it has adopted, Athens has produced serious arguments that Greece is the most reliable way to facilitate the integration of the Euro-Mediterranean energy market.

In addition, Greece has taken steps to expand the EU's area of responsibility by drawing attention to the role of the Eastern Mediterranean in the EU's energy security. In fact, all of those issues were in line with the EU's energy policies, which sought safe alternative supply corridors for energy security and diversity. Furthermore, oil and gas deposits discovered in the triangle of Egypt, Israel and Cyprus could increase the EU's influence on international energy markets. Again, thanks to the resources there, a new European energy network could be built and cooperation opportunities between members could be strengthened. When the situation is taken as a whole, it can be argued that the two members of the EU, Greece and SCGA, are trying to consolidate within the EU the understanding that the discovered resources could transform the EU's maritime jurisdiction areas into a regional energy center. As a matter of fact, those arguments were embodied in the short term and, within this framework, it was brought to the agenda that the electricity to be produced from a power plant to be established in the region would be sent to Europe via an undersea cable line with the construction of a pipeline that would transport the Eastern Mediterranean gas to Europe under the sea in cooperation with Israel, Cyprus and Greece.

Greece and Turkey are two rival states in foreign policy, which is an indisputable fact. Both countries have a big competition in the formation of energy geopolitics as in many other fields. To be

\footnotetext{
${ }^{2}$ To understand the conflict analysis to which the perception and competition in question were dragged, see: İsmail Şahin, Altuğ Günar, “Tavuk Oyunu Bağlamında Doğu Akdeniz'de (Kıbrıs) Meydana Gelen Gelişmelerin Analizi”, Ortadoğu Etütleri, 12/2, 2020, pp. 305-323. 
neutral, both countries have a mutually complementary role in the energy issue. However, the "expected" cooperation between the two countries has not been realized up to now. The historical problems between the two countries continue to undermine opportunities for cooperation. Until now, the general attitude of Athens has turned out to be in the form of excluding or isolating Turkey in the Eastern Mediterranean. The reason for it is the understanding and concerns mentioned above. According to Athens, Turkey attacks the sovereign rights of Greece and SCGA by acting against international law. Therefore, reconciliation with Turkey or negotiating the issues is not welcomed. Another claim of Athens is that the Turkish government is pursuing a policy of "Neo-Ottomanism" and thus trying to lead the Muslim Arab world (Mazis, 2012). According to that claim, the reason for Turkey's adoption of that policy is its desire to become an international hegemonic power by controlling the oil and gas fields of the Middle East. Interestingly, Athens interprets Turkey's support for democratic movements in North Africa and the Middle East in this context too.

\section{THE EFFECT OF THE EGYPTIAN REVOLUTION}

The decision of George Papandreou, the Prime Minister of Greece, to go to Egypt to meet with President Hosni Mubarak, with the support of the EU, right after the EU summit in Brussels, was a remarkable event. Papandreou was planning to convey the concerns of the EU and Greece to Mubarak during his visit to Cairo. However, Papandreou's visit announced on February 4, 2011 could not be realized due to Mubarak's resignation process. As a matter of fact, Mubarak announced his resignation on February 11. The Greek government, which closely followed the current developments in Egypt, continued to maintain its calm attitude after Mubarak's resignation. Evaluating Mubarak's resignation, Prime Minister Papandreou said that Greece supports the steps taken by the Egyptian people on the path of democracy and will maintain its stance in solidarity with them. Papandreou also drew attention to the historical ties and close relations between the two countries in his statement. In fact, the Greek government could not risk losing Cairo to Turkey. There were many reasons for it for Athens, from security to the economy. However, arranging a three-state exclusive economic zone border amongst Greece, Southern Cyprus and Egypt (Karyotis, 2011) was one of the main issues listed in order of importance by the Greek foreign policy at that time. Despite its composure, Greece was skeptical of the election victory of the Freedom and Justice Party founded by the Muslim Brotherhood after the January 25 Revolution and the subsequent election of Mohammed Morsi as the President. It is seen that the Greek government, on the one hand, tried to keep the ways of dialogue open with the new administration in Egypt, and on the other hand, it preferred to give more weight to the Greece-South Cyprus-Israel axis as a balancing factor to Turkey's rising foreign policy profile in the Middle East and North Africa. It was natural for Greece to resort to such a balancing strategy, as it was not possible for Greece to overcome the conflicts with Turkey in the Eastern Mediterranean on its own because, in the eyes of Athens, Turkey's gaining a diplomatic and military power in the Middle East and North Africa could 
have negative consequences for Greece. According to some, Turkey seized a historic opportunity to surround Greece from the south. There was also the energy aspect of the issue.

An exclusive economic zone (EEZ) agreement was signed between Egypt and SCGA in 2003. Athens started diplomatic initiatives to conclude a similar agreement, first with Egypt and then with SCGA, as a continuation of that agreement. Making EEZ agreements with Egypt and SCGA was one of the main axes of the foreign policy of the Greek New Democracy Party (ND) government (2004-2009). During that period, Prime Minister Costas Karamanlis set a goal to strengthen the country's position in the seas by signing EEZ agreements in the seas surrounding Greece, outside the Aegean. In this direction, on the one hand, Karamanlis was negotiating with Italy and Albania within the framework of determining the maritime jurisdiction areas in the Ionian Sea, on the other hand, he was holding talks with Libya and Egypt, two important countries of North Africa, in the Mediterranean. Egypt, in particular, was a key country to which Athens paid special attention due to its geopolitical position, importance and diplomatic weight in the Arab world.

The Greek government started to hold diplomatic talks with Cairo beginning from mid-2004 to delimit the maritime jurisdiction areas between the two countries due to its strategic importance. The ultimate aim of the government was to ensure the emergence of Greece's maritime jurisdiction areas as a whole with simultaneous agreements. The Greek government was planning to obtain effective support from the EU to achieve this goal. Therefore, an integrated maritime policy with a high emphasis on "joint sovereignty", which the EU could also defend, was adopted. According to the cleverly designed and used rhetoric, the national efforts of Greece and SCGA should be supported for the construction of a European EEZ that could extend to the far east of the Mediterranean as much as possible. In short, Athens worked hard diplomatically to promote the idea of a European EEZ in the Mediterranean; it made ingenious calls for the construction of a common policy and law to extend Europe's maritime borders across the Mediterranean and to establish fishing zones, power lines, and ecological protection areas over those sea. The main intention was to make the maritime jurisdiction disputes in the Eastern Mediterranean, to which Greece and SCGA were parties, a matter of the EU. In essence, the Karamanlis government dreamed of easily connecting the Greek-Libyan border line with SCGA-Egyptian border line thanks to the active support of the EU (Şahin, 2020). However, things did not go as planned and the planned agreements could not be signed. The change of power in Greece after the 2009 elections, ${ }^{3}$ the economic crisis that broke out in the country and the Arab Spring disrupted the agreements that were planned to be made between Greece and Egypt.

\footnotetext{
${ }^{3}$ PASOK, under the leadership George Papandreou, won the elections held on October 4, 2009 and came to power alone. 
It is seen that the cooperation steps between Greece and Egypt regarding the Eastern Mediterranean weakened in the period between Hosni Mubarak and Abdul Fattah al-Sisi. Relations between the two countries, covering energy and maritime jurisdiction areas, accelerated with the military coup that took place on July 3, 2013 in Egypt under the leadership of Abdul Fattah al-Sisi. While the military coup in Egypt deteriorated the relations between Turkey and Egypt, it enhanced the relations amongst Egypt, Greece and SCGA (Mehmet and Yorucu, 2020: 99). After that date, a new cooperation medium emerged amongst the three countries within the framework of joint energy works in the Mediterranean. Egyptian President Sisi, Greek Prime Minister Antonis Samaras and SCGA Prime Minister Nikos Anastasiadis, who met in Cairo in November 2014, agreed on the resumption of negotiations for the determination of the maritime border amongst the three countries (Al Jazeera Türk, 2014: Accessed 20.02.2021). Despite that decision, no rapid progress was made in the negotiations. However, the level of relations amongst the three countries continued to increase and eventually reached the point of strategic partnership. Sisi's increasing need for international support, who came to power with a military coup against the former Egyptian President Mohammed Morsi, made Greece and SGCA, two members of the EU, invaluable in the eyes of Sisi. As a matter of fact, the representatives of Athens and SCGA promised at the meeting in Cairo that they would "pursue Egypt's interests in the European Union and be the ambassadors of Egypt in the European Union" (DW, 2014: Accessed 20.02.2021).

It is quite remarkable that the negotiations between the two countries accelerated after the agreement between Turkey and Libya on the delimitation of maritime jurisdiction areas signed on November 27, 2019. As a matter of fact, with that agreement, Turkey both legalized and formalized its theses on the Eastern Mediterranean maritime jurisdiction areas at the international level. In the face of that development, Athens and Cairo signed a "partial" EEZ agreement on August 6, 2020 as a reaction to the Turkey-Libya agreement. Leaving aside the technical and legal aspects of the agreement, it is clearly understood that its ultimate aim is to abolish the maritime border between Turkey and Libya, and Turkey and Egypt. After that stage, the first priority of Greek diplomacy was to prevent possible Turkish moves that could harm the maritime jurisdiction areas agreement signed with Egypt. Its second priority was to preserve and keep alive the triple energy alliance agreed amongst Egypt, Southern Cyprus and Greece. Ultimately, what is essential for Athens is to implement and crown its regional gains against Ankara. In this respect, it attaches special importance to the East Mediterranean Gas Forum (EMGF) and the Eastern Mediterranean Pipeline Project (EastMed) because the ultimate goal of those two projects is to transport the natural gas to be extracted from the Eastern Mediterranean to Europe by "bypassing” Turkey with the EastMed pipeline project. When the economic discussions about the efficiency and sustainability of the project are put aside, ${ }^{4}$ it is obvious that the realization of such a project in its

\footnotetext{
${ }^{4}$ For an evaluation regarding the issue, see Bahrooz Jaafar, Doğu Akdeniz'de Enerji Boru Hatları ve Küresel Üretime Etkileri, İsmail Numan Telci, Recep Yorulmaz, (Ed.), Uluslararası Siyasette Doğu Akdeniz, Ortadoğu Yayınları, Ankara, 2020. Yönetim ve Ekonomi Arasttrmalart Dergisi / Journal of Management and Economics Research 
current form will increase the geopolitical value and importance of Greece. When the EastMed project, which envisions the delivery of Eastern Mediterranean natural gas to Europe via Greece, and the BurgasAlexandroupolis Oil Pipeline Project are considered together, it can be immediately noticed that both complement each other.

The biggest concern for Athens is the normalization of diplomatic relations between Turkey and Egypt, followed by the signing of a maritime authorization agreement between the two countries, which contradicts the arguments put forward by Greece. As a matter of fact, on February 18, 2021, the Egyptian government's stance considering Turkey's continental shelf claims within the scope of the announcement of license fields within the scope of oil and natural gas exploration activities in the Eastern Mediterranean caused great disturbance in the Greek government. Turkish Foreign Minister Mevlüt Çavuşoğlu's statement "we can sign an agreement with Egypt by negotiating maritime jurisdiction areas" in the atmosphere of ongoing disturbance, reactivated the diplomatic traffic between Athens and Cairo. Greek governments do not accept the thesis that Egypt, like Libya, is a maritime neighbor to Turkey. Acting upon that thesis, Athens argues that it is not possible for Egypt and Turkey to make a maritime delimitation agreement. Turkey, on the other hand, thinks exactly the opposite. According to Ankara, Turkey and Egypt are the two countries with the longest coastlines in the Eastern Mediterranean, and their coasts face each other. That is why, within the framework of international law, there is nothing that prevents the two countries from making a maritime jurisdiction delimitation agreement. However, Greece argues that the islands of Karaada (Ro), Çamada (Strongili) and Meis (Kastellorizo) have continental shelves and due to that special situation, the maritime border between Egypt and Turkey does not form. The negotiations between Egypt and Turkey are of vital importance in terms of Athens. A possible agreement to be signed between the two countries has the power to directly affect not only the claims of Greece in the Eastern Mediterranean, but also its claims of the continental shelf in the Aegean Sea. Therefore, the Greek government is trying to keep the Egyptian government close and to avoid incidents that could distort the relations between the two countries.

It has been mentioned above that since the beginning of the 2000s, Greece has had a policy of determining maritime jurisdiction areas in all seas except the Aegean Sea. The existence of that policy affects Athens' relations with the Arab world and Israel. Since the issue of Israel will be discussed later, it will not be discussed here now. In the Arab world, there were those who were sad as well as those who were happy when the Hosni Mubarak regime was overthrown. One of those who were sad was Saudi Arabia, one of Egypt's closest allies. As it is known, Egypt and Saudi Arabia were the two proWestern leading countries of the Arab world. Those two countries were also on the front against Iran, Hezbollah and Hamas. Saudi Arabia was also the dominant power in the Gulf Cooperation Council (GCC), which consists of Kuwait, Qatar, Bahrain, the United Arab Emirates (UAE) and Oman. Among 
those countries, Qatar openly supported the Arab Spring, and in the following period, it gave asylum to members of the Muslim Brotherhood. Turkey was one of the countries that acted together with Qatar. The search for democracy, called the Arab Spring, drew the pro-status quo countries and the anti-status quo countries into the struggle for the axis in a short time. At that point, the main foreign policy priorities of the GCC, consisting of oil monarchies, were in question. The first one is to prevent the Muslim Brotherhood from coming out of the Arab Spring process stronger. The second is to reduce Iranian influence in the region, especially in Syria. The third is to prevent a new Turkey-Qatar oriented political power from gaining influence in the region. After the failure of the Arab Spring, it is seen that the sanctions against Qatar in the summer of 2017 under the leadership of Saudi Arabia and the UAE were also expanded to the Eastern Mediterranean against Turkey in the following years. As a result of the implementation of the policy of containment and diplomatic isolation in the region by Saudi Arabia and the UAE towards, Turkey and Qatar, the foundations of a new anti-Turkey coalition in the Eastern Mediterranean were laid. The rapprochement between Saudi-UAE and Greece soon made itself evident in the Eastern Mediterranean, Cyprus and Libya. Within the framework of the Gulf-Mediterranean coalition, Saudi Arabia, UAE, Egypt, Israel, Greece and SCGA succeeded in forming an anti-Turkey front for the first time in the region. That new formation was well suited to the Greek policy of surrounding, isolating and suppressing Turkey. It is seen that the Greek government has intensified its diplomatic relations with Saudi Arabia and the UAE in order to strengthen its relations further and make permanent relations with the Gulf countries in tourism, energy, defense and diplomatic fields. The Mitsotakis government did not hold back from conducting exercises and making military agreements with the two countries at a level that would provoke Turkey's reaction. He did not even hesitate to make some important gestures. For example, the Greek government approved the delivery of one of the Patriot air defense batteries purchased from the United States to Saudi Arabia, and the agreement regarding the issue was signed in Riyadh in April 2021 between Greek Foreign Minister Nikos Dendias and Saudi Arabian Foreign Minister Prince Faisal bin Farhan. It is clearly perceived that the driving force behind the cooperation between Greece-SCGA and the Gulf countries in several areas in the Eastern Mediterranean was Turkey's policy related to the Eastern Mediterranean and Cyprus.

\section{GREECE'S CHANGING ISRAELI POLICY}

The political settled system in the Middle East and North Africa had to undergo a serious change with the discovery of energy resources in the Eastern Mediterranean and the social events called the Arab Spring. In that short but intense period, important political developments that could open new chapters in the history of diplomacy occurred. New challenges, shifting alliances, social ruptures and reshaped coalitions became the characteristic features of the period. The fluctuating relations between Greece and Egypt were evaluated above. Now, attention will be drawn to the normalization of relations between Greece-SCGA and Israel. When the diplomatic relations in the region is considered from a 
historical perspective, it is seen that after the first normalization in the region between Israel and Egypt, the first détente took place between Israel, and Greece-SCGA.

Greece was one of the countries that reacted most harshly to the establishment of Israel and accordingly voted against the United Nations Partition Plan for Palestine (1947). There were many reasons for it. Concern for oil, seeking support for the Cyprus issue, benefitting from the economic power of the Arabs, and efforts to defend the values and principles of Orthodox Christianity were among the main reasons. Despite the pressures from the European Union and the United States, Greece continued to pursue that policy resolutely for many years. On the other hand, Greece's relations with Arab countries generally followed a good course. Athens has always attached importance to bilateral and multilateral cooperation with the Arab world (Nachmani, 1987: 117-118). Among the countries in the region, Egypt has the most deep-rooted relations with Greece. The presence of the Orthodox Patriarchate of Alexandria and the Orthodox Greeks in the country provided an important opportunity for the two countries to cooperate closely. It is estimated that approximately 140,000 Orthodox Greeks lived in Egypt until the middle of the twentieth century, but that this number decreased rapidly due to various reasons in the following years and that this population has decreased to around 3500 as of today. Despite that serious erosion in the population, the Greek diaspora continues to be active in the commercial, political and cultural fields in Egypt. In addition, the fact that the Patriarchate of Alexandria is in charge of the entire African continent is another reason why Athens regards Egypt as a key country in relations with Middle Eastern and African countries. The positive relations between the two countries are also seen in the Cyprus issue. In this context, Egypt has always supported Greece and the Greek Cypriots on the Cyprus issue. Due to the factors above, Athens decided to recognize Israel de facto (1949) and refused de jure recognition until 1990. It is possible to mention a Greek population spread not only in Egypt but also throughout the Arab world. Those people are known to have considerable influence though their numbers are small in the countries they live. As it has been briefly mentioned above, it is an important detail to consider the relations of the Orthodox Patriarchate of Jerusalem and the Orthodox Patriarchate of Alexandria with Greek governments. In conclusion, the national interests of Greece and the Greek religious institutions and diaspora in the Arab world have played a strong role in preventing the Greek government from establishing full diplomatic relations with Israel.

The main parameters of Greece's Palestine policy can be summarized as the establishment of an independent Palestinian state with East Jerusalem as its capital and Israel's return to the pre-1967 borders. Athens granted diplomatic status to the Palestine Liberation Organization (PLO) on December 16, 1981 within the framework of finding a comprehensive two-state solution in Palestine; Greece supported Palestine's decision to join UNESCO in November 2011. Nevertheless, it is possible to say that the Greek governments avoided being actively involved in the Arab-Israeli conflict. However, the Greek governments, which carried out activities in favor of the Palestinian administration before the 
European Union and the United Nations, did not hesitate to show their solidarity with the Palestinians by not recognizing Israel until as late as May 21, 1990.

The reason why Greece's relations with Israel were bad until that date was not only the Palestinian issue. There was also a religious and social aspect of the issue. Except for the Ottoman period, it can be said that relations between Greeks and Jews were generally bad until recently (Tziampiris, 2015: 41). For centuries, Greece has been one of countries where a large population of Jews lived. This situation began to undergo a major change with the independence of Greece (1830). In the post-independence period, Jews were adversely affected by the demographic structure that underwent a transformation in Greece. Independence did not benefit the Jewish population. The activities that became manifest in the form of discrimination, ill-treatment and exclusion over time forced the Jews to migrate from their lands, where had been living for a long time. According to the research, just before the Second World War, approximately 70,000 Jews lived in Greece, with most of the population in Thessaloniki (Bowman, 1986: 50-51). The Italian and German occupation of Greece during the war brought a great disaster not only to the Greeks but also to the Jews living in that country. While the Greeks were struggling with war and famine, the Jews were also subjected to genocide in addition. Most of the population was gathered and sent to Nazi death camps. According to official records, the number of Jews who fell victim to Nazi persecution in Greece is $67,151 .{ }^{5}$ Almost all of the Jewish population in Greece was lost as a result of war, famine, immigration, exile and genocide conditions. The silence of the Greek public in the face of that persecution, and the usurpation of those people's wealth and properties in the following years, are remembered as a painful event that dominated the Israeli-Greek relations. The fact that the number of Jews living in Greece today has declined to around five thousand is important in that it indicates the demographic erosion of Greek Jews.

\section{RECOGNITION AND DÉTENTE}

Greece recognized Israel on May 21, 1990. That recognition occurred at a time when the conservative New Democracy Party (ND), located on the center-right, was in power alone. The fact that no significant protest, condemnation or embargo reaction emerged from any Arab state to this development, which is considered a turning point between the two countries, relieved Athens. After all, the government did not want the decision of recognition to harm the existing relations with the Arab world. Party leader and Prime Minister Konstantin Mitsotakis (1918-2017) was a politician who favored improving relations with Israel from the very beginning. Mitsotakis, who took over the prime ministry in an environment where the Soviet Union was beginning to disintegrate and the Cold War conditions

\footnotetext{
${ }^{5}$ That figure was expressed by Nikolaos Voutsis, the chairman of the parliament in the special session called "Greek Holocaust Victims and Heroes" held in the Greek Parliament on January 27, 2016. For detailed information, see: https://www.hellenicparliament.gr/Enimerosi/Grafeio-Typou/Omilies-Proedrou/?press=c6a89141-c107-453f-b559a59a00fe95cc (Accessed) 30.12.2020). 
were about to end, believed the anti-Israeli stance of PASOK (Panhellenic Socialist Movement) harmed the interests of Athens. Therefore, he recommended that necessary steps be taken to improve relations with Israel gradually, measuredly and in a way that would not disturb the Arab states. Another important issue affecting the relations between Israel and Greece was Cyprus. Israel has taken sides with Turkey on the Cyprus issue since its establishment. This position of Israel made an important contribution to the anti-Israelism in Athens and South Cyprus. The anti-Israel opposition in the Greek public became more intense with Turkey's intervention in Cyprus in particular. It can be said that the Peace Operation (1974) had a reinforcing effect on the nationalist, anti-American and pro-Palestinian view in Greece. Naturally, it also affected Greece's view of Israel. PASOK leader Andreas Papandreou, who became prime minister in 1981, did not hesitate to say that he found Israel's actions to be "pro-Fascist-Nazi" (Tziampiris,, 2015: 47-48), and he aggravated the burden of relations. PASOK's anti-Israel campaign peaked with the invasion of Lebanon by Israel (1982). The Papandreou government not only condemned Israel, but also had the courage to send four ships to evacuate Arafat and his men from Lebanon (Abadi, 2000: 58). The invasion did not only provoke a reaction from the government but also anti-Israel protests organized by NGOs, especially trade unions, spread in waves in Greece (Nachmani, 1987: 120). Initially, PASOK was unmistakably anti-Israeli and though that position weakened over time, it maintained its general lines by softening them throughout its 19 years in power. ${ }^{6}$

As a matter of fact, during the $80 \mathrm{~s}$, when the Socialist PASOK (Panhellenic Socialist Movement) led by Andreas Papandreou was in power, relations with the USA and Israel were not at a "satisfactory" level. During Papandreou's premiership, Greece had a reputation as the most pro-Palestinian country in Europe. Athens was one of the biggest supporters of the Palestine Liberation Organization (PLO) in Europe during those years, and Prime Minister Papandreou had a close relationship with PLO leader Arafat. Known for his anti-US and anti-Israel rhetoric, Papandreou concretely demonstrated his political stance by granting diplomatic status to the PLO on December 16, 1981. Mitsotakis showed when he was in opposition that he did not intend to continue that political legacy and publicly promised to repair relations with the two countries (Abadi, 2000: 62). During their visit to Israel in May 1988, Mitsotakis and some ND members even repeated their promise to establish diplomatic relations with Israel if they won the elections. Mitsotakis was quick to keep his promises. Mitsotakis became the prime minister in April 1990, recognized Israel on May 21 and made an official visit to the United States in June. Both events were of historical significance. Mitsotakis was the first Greek prime minister to visit Washington in 26 years (Feighan, 1990). Greece's anti-Israel and anti-US policy was broken, and the doors of a new era were opened amongst the trio. Both of Athens' diplomatic steps coincided with a period when Israel and Turkey established close military and economic relations. In fact, what actually happened was a certain degree of Europeanization of Greek foreign policy towards Israel. In addition, it is necessary to 
take into consideration the fundamental changes that occurred in the international system. In the mid1980s, Soviet Union leader Mikhail Gorbachev's tendency towards liberalization reforms called "Perestroika" and "Glasnost" but, in spite of it, the collapse of communist regimes in Central and Eastern Europe, one by one, heralded the collapse of the bipolar system. In an international political environment where the USA became the world's sole superpower, it was not surprising that the pro-American Mitsotakis took bold steps to recognize Israel. Important regional developments such as the Intifada that started in 1987, the establishment of Hamas in the same year, and the US's active intervention in the Middle East with the Gulf War can be evaluated as developments that encouraged Mitsotakis.

Spain's recognition of Israel in 1986 weakened Greece's hand. Spain had been against Israel for years. After Spain's recognition, Greece remained the only state that did not officially recognize Israel in the European Union due to the Palestinian issue (Abadi, 2000: 64). It is also possible to come across claims that the Greek Ministry of Foreign Affairs gave the green light to officially recognize Israel after Madrid's decision to recognize Israel due to pressures from Europe and the changing conjuncture, but postponed this decision due to the First Intifada that broke out in December 1987 (Tziampiris, 2015: 50). As a matter of fact, Greek Foreign Minister Karolos Papoulias stated on February 23, 1987 that the government was seriously considering recognizing Israel officially (Abadi, 2000: 64). In fact, during the second period of PASOK's rule (1985-89), a softening in the rhetoric used related to Israel was observed (Abadi, 2000: 40). The most notable event during that time was Athens' refusal to support the First Intifada. The reason why the PASOK government avoided it was, besides the regional conditions, perhaps the Islamic groups in Palestine coming to the fore in the Intifada. It should also be remembered that after the EU membership, Athens gradually started to pursue a policy in the orbit of the EU related to the Middle East (Tsardanidis and Stavridis, 2005: 217-239).

The invasion of Kuwait by Iraqi President Saddam Hussein on August 2, 1990 and the launch of Operation Desert Storm (Gulf War) on January 17, 1991 by the US-led coalition forces in response to that invasion opened the door to significant changes in regional conditions. In this process, it can be argued that the Palestinian leader Arafat's support of Saddam and remaining alone in the eyes of the Arab world and the powers that joined the coalition opened a new diplomatic maneuvering space for Athens. As a matter of fact, the Greek government was on the side of the coalition forces in the Gulf War along with Israel, and it presented a position that served to improve bilateral relations. Prime Minister Mitsotakis paid an official visit to Israel in 1992. It was the first time a Greek Prime Minister visited Israel. The taboos and walls between the two countries began to fall one by one. A Defense Cooperation agreement was signed between Athens and Tel Aviv in 1994. However, this agreement could not go beyond the signature because in addition to distrust and uneasiness between the two sides, there was also a concern about maintaining regional balances. As mentioned above, the most serious 
concern for Greece was to lose the friendship of the Arab world and gain its hostility (Ersoy, 2019: 121). As for Israel, it was unwilling to take on an ally like Turkey, which had problems with Greece. Nonetheless, relations between the two countries made great progress in all aspects during the 90s. Along with political and military relations, social ties were not neglected. In this context, monuments were erected in Thessaloniki (1997) and Athens (2010) for the Greek Jews who died in the Holocaust (Tziampiris, 2015: 50-51). Relationships that started in the 90s moved to the 2000s without any crisis or interruption. Relationships that started badly in the first century were repaired and even improved as the second century started. The official visit of Greek President Konstantin Stephanopoulos to Israel in May 2000 reflected the strategic steps taken in the previous 10 years. The agenda of the President, who did not meet with Palestinian officials, included raising bilateral relations to higher levels. The USA openly supported the rapprochement between Israel and Greece. It was one of the most fundamental policies of Washington to strengthen relations between western-oriented states in the eastern Mediterranean. Israel's growing need for security, its vital ties with the EU and the United States, and Greece's approach to gaining a new ground in regional issues brought the two countries closer in a way to coordinate their foreign policies better. Establishing strong relations with the non-Arab countries of the region was Israel's main foreign policy priority. ${ }^{7}$

By the 2000s, Greece was more eager to develop relations with Israel. Firstly, the conjuncture had radically changed. The United States was now the dominant power in the international system. A new era began and the ongoing anti-American rhetoric remaining from 1974 would not benefit Athens. Gaining power and influence in the eyes of America could be achieved with Israel. Besides, the pragmatist relations established with the Arab countries did not contribute to the solution of the Cyprus problem. What is more, the focus of the Cyprus issue shifted to the EU rather than the UN, with the GSCA becoming an EU member in 2004. This situation allowed Greece to get closer to Israel more easily. It will be appropriate to add the pro-American attitudes of Arab states to this equation. On the other hand, despite its interests in improving relations with Greece, Israel avoided being a party to the Turkish-Greek disputes for a long time. The Athens Summer Olympics (2004) was important in that it allowed the two countries to work closely on security and terrorism issues. Israel played an important role with the technical and tactical information it provided in eliminating Greece's growing concerns about international terrorism due to the Olympics. Another remarkable development that paved the way for cooperation between the two states took place at the beginning of 2004. The Greek Parliament declared January 27 as a day of commemoration and honor for the Greek Jews who lost their lives in the Nazi concentration camps with a unanimous decision. The unanimity of the decision was quite

\footnotetext{
${ }^{7}$ To obtain a wider perspective regarding the issue, see: Efraim Inbar, Israel's National Security Issues and challenges since the Yom Kippur War, Routledge, New York, 2008. 
Yönetim ve Ekonomi Araștırmalarl Dergisi / Journal of Management and Economics Research

Cilt/Volume: 19 Sayl/Issue: 3 Eylül/September 2021 ss./pp. 115-138

İ. Şahin, H. Yazıc1 http://dx.doi.org/10.11611/yead.974239

remarkable in that it reflected the parties' viewpoints related to normalization and rapprochement with Israel.

The relations between Athens and Tel Aviv started to enhance in the course of time in parallel with the regional developments. In this context, the elections held in Palestine on January 25, 2006 became a turning point in terms of regional relations (Çubukçu, 2006). The death of Yasser Arafat, the internationally recognized charismatic leader of Palestine, on November 11, 2004, accelerated the declining process of the representation ability of Fatah among the Palestinian people. This situation was observed in the January 25, 2006 elections; Hamas won 74 of the 132 seats in the parliament. This "unexpected" electoral victory of Hamas, which did not recognize the Oslo Agreement and Israel, greatly disturbed the actors, especially Israel, who doubted the existence of Hamas. After all, there was not just a political rivalry between Hamas and Fatah; in addition to important ideological differences between the two groups, there were also deep gaps in their perspectives on the Palestinian issue. Initially, Hamas described Israel as an "existential threat" and regarded its struggle far beyond a border dispute. In this context, Hamas has defined Israel as "a project of Western Zionist imperialism" that aims to shatter the unity and integrity of the Arab world (Al Jazeera Türk, 2014: Accessed 11.01.2021). Unlike Hamas, the Palestine Liberation Organization (PLO), which gathered various resistance groups that think differently from one another under the same roof, sought a solution based on two states with the declaration of the establishment of the State of Palestine on November 15, 1988. PLO turned to look for a solution through diplomatic struggle in the next period and, in this context, no longer regarded the goal of destroying Israel as the only option (Karaman, 1996: 103-106). It was an important transformation.

The connection of Hamas with the Muslim Brotherhood, also known as al-Ikhwan, one of the oldest organizations in the Arab world, and the movement of the struggle in Palestine from the nationalsecular line to the national-Islamic line after 2006 were one of the developments that disturbed Israel. It can be argued that a similar concern was also present in Athens. The strongest aspect of Hamas was that it came to power after legitimate elections held through democratic methods. Its weakest point was that it won the elections at a time when the attacks of September 11 kept the world in suspense. Hamas was included in the list of terrorist organizations by the EU and the USA in 2001.

In an environment where international politics were so heavy, Israeli President Moshe Katsav paid an official visit to Athens on 14-16 February 2006 in order to enhance the relations between the two countries and to get the support of Greece on the Palestine issue. In that period, seeking political support against Hamas was seen as the biggest and most urgent issue for Israel. Moshe Katsav was the first Israeli president to make an official visit to Greece. The main expectation of Israel from Greece in those years was to develop cultural, commercial and political relations based on mutual benefits. Moshe Katsav emphasized the common values between the two countries during his visit, and he conveyed the 
Yönetim ve Ekonomi Araștırmaları Dergisi / Journal of Management and Economics Research

Cilt/Volume: $19 \quad$ Sayl/Issue: 3 Eylül/September 2021 ss./pp. 115-138

İ. Şahin, H. Yazıcı http://dx.doi.org/10.11611/yead.974239

message to the Greek part that Israel-Greece relations could be improved without disturbing the relations between Greece and the Arab world, and the relations between Israel and Turkey.

During those years, the New Democracy Party (ND) was in power under the leadership of Kostas Karamanlis, who won the 2004 elections. Established by Konstantin Karamanlis in 1974 during the collapse of the junta administration in Greece and the country's transition from military dictatorship to democracy, the main policy of ND was to consolidate Greece's relationship with its western allies (Featherstone, 1982: 187). It differed from PASOK in this respect. As emphasized above, ND was in favor of developing Greek-Israeli relations. Besides, it will be seen that the relations between the two countries made progress when ND was in power. Important political developments such as recognition of Israel, cooperation agreements and establishing high-level relations took place when ND was in power. In this context, ND attached importance to the restoration of democracy in the country, integration with Europe and relations with NATO. In addition, ND pursued a policy that preferred to find solutions to the conflicts with Turkey through diplomatic means rather than military options (Clogg, 1997: 208). However, in disputes about Turkey, the understanding of gaining superiority over Ankara with the guardianship and support of European diplomacy has been the main strategy of ND since the founding leader Karamanlis. The special relationship that ND developed with Europe and the USA had a positive effect on the country's policies towards Israel, especially between 1990 and 1993, and between 2004 and 2009, when it was in power alone. The developments that took place at the regional level eliminated the ideological differences between Greece and Israel after a certain period of time. At least, they ceased to be an obstacle to cooperation. Thus, PASOK, led by George Papandreou, who won the 2009 elections, and Likud party, led by Benjamin Netanyahu, were able to advance the relations between the two countries.

\section{CONCLUSION}

Initially, there were many factors that determined the Greek policy towards Israel. They can be summarized as the Greek religious institutions and diaspora in the Arab world, the dependence on Arab oil and the need for Arab support at the UN on Cyprus. It is possible to say that they prevented Athens from pursuing a flexible and versatile foreign policy in the Middle East. It is understood that until that flexibility and versatility were established, no political party in Greece was willing to establish a close relationship with Israel. In addition to them, it is seen that the Greek governments had a political attitude towards Israel in the context of their relations with the countries within the Non-Aligned Movement. That policy was quite suitable for the conditions of the Cold War Period for Athens. After all, it is known that the theses of both Greece and the Greek community in Cyprus are mostly supported by the Third World Countries, which have a significant number in the UN General Assembly. Therefore, it can be argued that the Greek governments are careful not to break off their relations with the Third World 
Countries and the Arab world. It is quite remarkable that Greece maintained that attitude even during the period of Gamal Abdul Nasser, who caused difficulties for the Greek diaspora in Egypt.

Greece's anti-Israel attitude increased noticeably in the first years of PASOK's rule. However, in the following years, the prominence of the Islamic identity in Palestine, the failure to receive the expected support from the Arabs on the Cyprus issue, and the increasing pressures with the EU membership were developments that softened the anti-Israel rhetoric in Greece. The radical change that occurred in the international system with the disintegration of the Soviet Union and Yugoslavia in the early 1990s had a significant impact on Athens' Israel policy. That change manifested itself in the years when the New Democracy Party (ND) was in power. In the long run, PASOK could not resist the normalization process initiated by the New Democracy Party against Israel and it also got involved in this process. In addition, it was regarded as a rational choice for Athens to invest in the future of American-Greek relations through Israel in that period in the unipolar international system in which America was the hegemonic power. In addition, it is noticeable that Greece gradually started to follow a policy similar to that of the EU in the Middle East with the EU membership.

In this study, the relations between Greece and Egypt are mentioned in general terms. The point that needs to be emphasized here is the uneasiness caused by the Egyptian Revolution and the process of Mohammed Morsi's coming to power in Athens. The anxiety arising from this uneasiness pushed Israel and Greece into closer cooperation. As a matter of fact, the Morsi government posed a risky situation for the security of both countries. Morsi's close dialogue with Turkey and the possibility of the two countries acting jointly in the Eastern Mediterranean were the main concerns for Greece. As a matter of fact, it led to the thought that a possible EEZ agreement between Egypt and Turkey could greatly damage Athens's thesis on the Eastern Mediterranean, Cyprus and the Aegean Sea. Besides, the strong ties that could be established between Turkey and Egypt were also contrary to the historical containment policy that Greece tried to implement against Turkey.

It should not be overlooked that the Arab Spring coincided with a period when natural gas was discovered in the sea areas amongst Israel, Cyprus and Egypt. This situation caused Egypt to gain prominence in terms of energy security in the region. Therefore, the regime and power change in Egypt was seen as dangerous for Israel's security on the one hand and it was perceived as a serious threat to Greece's national interests on the other. Turkey-Israel relations that developed in the context of the Mavi Marmara Incident should definitely be added to all this.

\section{REFERENCES}

Abadi, J. (2000) “Constraints and Adjustments in Greece's Policy toward Israel”, Mediterranean Quarterly, 11(4): 40-70. 
AJC, (2020) https://www.ajc.org/news/four-things-jews-should-know-about-greek-prime-ministerkyriakos-mitsotakis

Al Jazeera Türk (2014) http://www.aljazeera.com.tr/haber/misir-yunanistan-rum-yonetimi-zirvesi (20.02.2021).

Al Jazeera Türk, (2014) http://www.aljazeera.com.tr/dosya/islami-direnis-hareketi-hamas (11.01.2021).

Amikam, N. (1987) "Israel, Turkey and Greece: Uneasy relations in the East Mediterranean", London, Frank Cass.

Bowman, S. (1986) "Jews in Wartime Greece”, Jewish Social Studies, 48(1): 45-62.

Clogg, R. (1997) “Modern Yunanistan Tarihi”, Transl. Dilek Şendil, Istanbul, İletişim Yayınları.

Çubukçu, M. (2006) "Filistin, Hamas'la İslamileşiyor", Birikim, 202. https://birikimdergisi.com/dergiler/birikim/1/sayi-202-subat-2006/2386/filistin-hamas-laislamilesiyor/6167 (10.01.2021)

DW (2014) https://www.dw.com/tr/do\%C4\%9Fu-akdenizde-stratejik-ortakl\%C4\%B1k/a-18056309 (20.02.2021).

Ersoy, T. (2019) "Emerging Alliances, Deteriorating Relations: Turkey, Israel and Greece in the Eastern Mediterranean”, Ayşegül Sever, Orna Almog (Ed.), Contemporary Israeli-Turkish Relations in Comparative Perspective, Switzerland, Palgrave.

Featherstone, K. (1982) “Elections and Parties in Greece”, Government and Opposition, 17(2): 180-194.

Feighan, E. R. (1990) "A New Era in Greek-US Relations", The Christian Science Monitor. https://www.csmonitor.com/1990/0619/efeig.html (02.02.2021).

Harlaftis, G. (1996) “A History of Greek Owned Shipping”, London, Routledge.

Heraclides, A. (2002) "Yunanistan ve "Doğu'dan Gelen Tehlike” Türkiye”, Transl. Mihalis Vasilyadis, Herkül Millas, Istanbul, İletișim Yayınevi.

Inbar, E. (2008) "Israel's National Security Issues and challenges since the Yom Kippur War", New York, Routledge.

Jaafar, B. (2020) “Doğu Akdeniz'de Enerji Boru Hatları ve Küresel Üretime Etkileri”, İsmail Numan Telci, Recep Yorulmaz, (Ed.), Uluslararası Siyasette Doğu Akdeniz, Ankara, Ortadoğu Yayınları. Karaman, M. L. (1996) “Filistin Kurtuluş Örgütü”, Istanbul, TDV İslam Ansiklopedisi, 13: 103-106.

Karyotis, T. (2011) "Continental shelf and EEZ, myths and reality", Kathimerini. https://www.kathimerini.gr/politics/445226/yfalokripida-kai-aoz-mythoi-kai-pragmatikotita/ (20.12.2020). 
Le Corre, P. (2018) “Greece: A Maritime Nation Now at the Heart of the Maritime Silk Road", Carnegie Endowment for International Peace, Research Report, 12-21.

Mazis, I. T. (2012) "The Israel-Cyprus-Greece geostrategic axis", Foreign Affairs. http://www.foreignaffairs.gr/articles/68736/ioannis-th-mazis/o-geostratigikos-aksonas-israilkyproy-ellados?page=show (12.01.2021).

Mehmet, O. and Yorucu, V. (2020) "Modern Geopolitics of Eastern Mediterranean Hydrocarbons in an Age of Energy Transformation", Switzerland, Springer.

Mekel, A. (2019) “A New, Pro-Israel Government in Athens”, BESA Center Perspectives Paper No. 1,231. https://besacenter.org/perspectives-papers/greece-pro-israel-government/

Pevehouse, J. C. and Goldstein, J. S. (2015) "Uluslararası İlişkiler”, Transl. Haluk Özdemir, Ankara, BB101 Yayınlar1.

Şahin, İ. and Günar, A. (2020) “Tavuk Oyunu Bağlamında Doğu Akdeniz’de (Kıbrıs) Meydana Gelen Gelişmelerin Analizi”, Ortadoğu Etütleri, 305-323.

Şahin, İ. and Günar, A. (2021) “Türkiye'nin Doğu Akdeniz ve Kıbrıs Siyaseti”, Tayyar Arı-Mesut Hakkı Caşın (Ed.), Uluslararası Güç Mücadelesinin Yeni Arenası Doğu Akdeniz, Istanbul, İdeal Kültür Yayıncilik.

Tsardanidis, C. and Stavridis, S. (2005) “The Europeanisation of Greek foreign policy: A critical appraisal”, Journal of European Integration, 27(2): 217-239.

Tziampiris, A. (2015) “The Emergence of Israeli-Greek Cooperation”, Switzerland, Springer. 


\begin{tabular}{|c|c|c|}
\hline $\begin{array}{c}\text { KATKI ORANI / } \\
\text { CONTRIBUTION RATE }\end{array}$ & $\begin{array}{l}\text { AÇIKLAMA / } \\
\text { EXPLANATION }\end{array}$ & $\begin{array}{c}\text { KATKIDA } \\
\text { BULUNANLAR / } \\
\text { CONTRIBUTORS }\end{array}$ \\
\hline $\begin{array}{c}\text { Fikir veya Kavram / Idea } \\
\text { or Notion }\end{array}$ & $\begin{array}{l}\text { Araştırma hipotezini veya } \\
\text { fikrini oluşturmak / Form the } \\
\text { research hypothesis or idea }\end{array}$ & 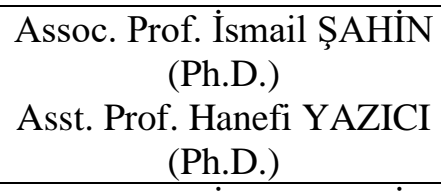 \\
\hline Tasarım / Design & $\begin{array}{l}\text { Yöntemi, ölçeği ve deseni } \\
\text { tasarlamak / Designing } \\
\text { method, scale and pattern }\end{array}$ & 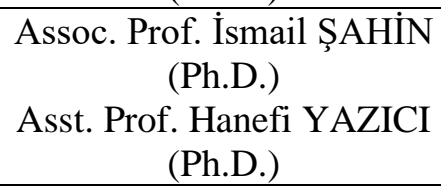 \\
\hline $\begin{array}{c}\text { Veri Toplama ve İşleme / } \\
\text { Data Collecting and } \\
\text { Processing }\end{array}$ & $\begin{array}{c}\text { Verileri toplamak, } \\
\text { düzenlenmek ve raporlamak / } \\
\text { Collecting, organizing and } \\
\text { reporting data }\end{array}$ & $\begin{array}{l}\text { Assoc. Prof. İsmail ŞAHIN } \\
\text { (Ph.D.) } \\
\text { Asst. Prof. Hanefi YAZICI } \\
\text { (Ph.D.) }\end{array}$ \\
\hline $\begin{array}{l}\text { Tartışma ve Yorum / } \\
\text { Discussion and } \\
\text { Interpretation }\end{array}$ & $\begin{array}{c}\text { Bulguların } \\
\text { değerlendirilmesinde ve } \\
\text { sonuçlandırılmasında } \\
\text { sorumluluk almak / Taking } \\
\text { responsibility in evaluating } \\
\text { and finalizing the findings }\end{array}$ & $\begin{array}{l}\text { Assoc. Prof. İsmail ŞAHIN } \\
\text { (Ph.D.) } \\
\text { Asst. Prof. Hanefi YAZICI } \\
\text { (Ph.D.) }\end{array}$ \\
\hline $\begin{array}{l}\text { Literatür Taramas1 / } \\
\text { Literature Review }\end{array}$ & $\begin{array}{c}\text { Çalışma için gerekli literatürü } \\
\text { taramak / Review the } \\
\text { literature required for the } \\
\text { study }\end{array}$ & $\begin{array}{l}\text { Assoc. Prof. İsmail ŞAHİN } \\
\text { (Ph.D.) } \\
\text { Asst. Prof. Hanefi YAZICI } \\
\text { (Ph.D.) }\end{array}$ \\
\hline
\end{tabular}

Hakem Değerlendirmesi: Dış bağımsız.

Çıkar Çatışması: Yazar(lar) çıkar çatışması bildirmemiştir.

Finansal Destek: Yazar(lar) bu çalışma için finansal destek almadığını beyan etmiştir.

Teşekkür: -

Peer-review: Externally peer-reviewed.

Conflict of Interest: The author(s) has/have no conflict of interest to declare.

Grant Support: The author(s) declared that this study has received no financial support.

Acknowledgement: - 